\title{
Existing dairy buffalo production system under intensive condition in drought prone Dinajpur district of Bangladesh
}

\author{
S.M.R. Rahman*, M.N. Islam, M.H. Rashid, N.R. Sarker' ${ }^{1}$, M.S.R. Siddiki, and M.A. Islam \\ Department of Dairy Science, Bangladesh Agricultural University, Mymensingh 2202, Bangladesh \\ ${ }^{1}$ Bangladesh Livestock Research Institute, Savar, Dhaka-1341, Bangladesh
}

\begin{abstract}
An attempt was made to study the existing production and management system under intensive buffalo farming at Dinajpur district, a drought area of Bangladesh. Thirty two farmers were selected for this study. Direct interview with farmers, farm observation, community discussions and key informant interview (KII) were carried out to achieve the study. Two types of intensive system were found, namely - household yard (HYI) and completely intensive (CI). It was observed that in HYI system during the day time the animals were kept in yard and in confinement at night. On the contrary, animals were always remained in the shed under CI system. Feeding practice and utilization of feed resources were found different in HYI and CI farming. Showering of dairy buffaloes was observed as common practices in both production systems. All productive e.g. milk yield, lactation yield, lactation length and dry period and reproductive traits e.g. service per conception, age at first pregnancy, age at first calving and post/partum heat period under CI production system were found significantly $(\mathrm{p} \leq 0.05)$ better than that of the HYI systems. Significantly $(\mathrm{p} \leq 0.05)$ higher total solids and fat were found in milk from CI system compared to the HYI system, but in case of protein it was opposite. Natural breeding showed as more prominent practice than that of the artificial insemination in both farming systems. All the farmers practiced colostrum feeding and the calf mortality ranges from 7-8\%. Regarding the primary health care, CI farmers were found to be more attentive than the HYI farmers. Most of the buffaloes showed heat from early night to early morning (78.7\%). Problem matrix revealed that the top ranked order of problems were "inadequate knowledge", "high price of feed" and "low milk price". However, both systems were found as a profitable venture (benefit cost ratio1.33 in HYI and 1.25 in CI).
\end{abstract}

(Key words: Buffalo production, Feeding, management Milk quality)

\section{Introduction}

The farming systems of animal agriculture consist of buffaloes (Bubalus bubalis) and other livestock resources in Bangladesh. Buffalo milk and meat (buffen) is more beneficial than that of the cattle. Buffen contains 40\% less cholesterol, 55\% less calories, $11 \%$ more protein and 10\% more mineral in comparison to the bovine meat (Nanda and Nakao, 2003). Buffalo milk has $43 \%$ less cholesterol, $58 \%$ and $40 \%$ more calcium and protein, respectively than that of the cow's milk. It is also a rich source of iron, phosphorus, vitamin A and of course protein (Bilal et al., 2006). In addition, Islam et al. (2015) reported no allergenic epitopes of $\beta$-lactoglobulin from Bangladeshi Buffalo milk. According to Bilal et al. (2006), Buffen is more preferable over the beef for cholesterol sanative people.

There are 1.47 million heads buffaloes in Bangladesh (DLS 2016). Though the growth trend of buffalo population (2.20\%) in recent year is relatively higher than that of the cattle $(0.44 \%)$ but buffalo milk production is not contributed significantly to the national milk

*Corresponding author: smrajiurrahman@yahoo.com

Bang. J. Livs. Res. Special Vol. 21-25, 2018: P. 103-117, ISSN 1022-3851 
production of Bangladesh (Islam, 2017). Total milk production of Bangladesh is about 9.40 million metric tons per year (MMT) against the requirement of 15.29 MMT (DLS 2018). To address the gap of demand and availability of milk, another dairy species e.g. buffalo should be prioritized along with cattle, considering the contribution of buffalo to the national milk production of India and Pakistan. In Bangladesh, the concentration of buffaloes is higher in the coastal areas and northern part of Bangladesh placed second in this regards (Huque and Khan, 2017).

Several production system of buffaloes based on management practices and feeding system are found in Bangladesh (Rahman et al., 2018; Saadullah, 2012). At the village level, production is usually based on a small herd of mixed ages and sexes generally for milk and breeding purposes. In a semi-intensive production system, buffaloes are kept mainly for specific purposes, i.e., either for milk or for meat production. Larger herd is kept for both milk and meat purpose in saline coastal areas under extensive system. In the village production systems, buffaloes and cattle are kept together within the shed at night, and spend the daytime household yards for feeding and resting. In river basin areas, buffaloes are reared under semi-intensive system. In this system, buffaloes are kept within the shed at night and spend daytime for grazing in the Bathan. Besides, a few numbers of intensive buffalo farming have also been seen in some institutional herd as well as at farmer's level. Household intensive system are very scattered and mainly seen at Northern part of Bangladesh, e.g. Dinajpur, Rangpur, where, the buffalo feeding is supported by intensive irrigated agriculture system. Soliman (2007) concluded that the national strategies for the irrigated intensive agricultural system in developing countries should focus less expensive milk production from dairy buffaloes that efficiently utilize the inexpensive feed resources. The total milk yield per lactation and lactation period varied among the systems due to availability of feed resources, management systems and genotypes of buffaloes. The buffalo raised under household or semi-intensive system produced higher milk than the bathan or extensive system. The lactation yield in the household farming or semi-intensive system and bathan farming or extensive system were found 712-799 and $435 \mathrm{~L}$, respectively by Faruque et al. (1990) and Uddin et al. (2016). Uddin et al. (2016) reported that the average age at first heat was between 39 and 40 months in both household and bathan farming. They also noted that the average service per conception, gestation length, calving interval, and post partum heat period were 1.9 and 2.1, 310 and 315 days, 390 and 420 days and 125 and 130 days, respectively in household and bathan buffalo farming. All these demonstrated about the productive, reproductive performances of dairy buffaloes under different management system in Bangladesh. Rahman et al. (2017) felt the insufficiency about the information on intensive buffalo farming system. Rahman and Islam (2018) reported very scattered two types of intensives buffalo farming in the Dinajpur district. However, there are ample opportunities to contribute more data on buffalo production system in Bangladesh. Moreover India, Pakistan, Trinidad, Brazil, Italy and some other country have been started intensive buffalo farming to increase their national milk production (Naher, 2011). Therefore, this study was undertaken to know the feeding, breeding, management practice and associated problems, and productive and 
reproductive performances of dairy buffaloes under intensive system of dairy buffalo farming in Dinajpur district of Bangladesh.

\section{Materials and Methods}

\section{Location of study areas}

Considering the availability of buffalo farmers and agricultural production system, Birganj, Kaharol and Dinajpur sadar sub-district under Dinajpur district of Bangladesh were selected for this study. Some information of these areasis given in Table1. having at least one milking buffalo with calf.

\section{Preparation of questionnaire}

Structured questionnaire (containing both open and closed questions) was developed to collect data according to the objectives. Variables like productive and reproductive performances, feeding, breeding, and healthcare and other management practices with related problems for dairy buffalo farming were considered. Data were collected using standard procedure. The questionnaire was pre-tested in the selected areas and modified accordingly. Farm visit, farm

Table1. Location, human population density and farm types in Birganj, Dinajpur sadar and Kaha role sub/district

\begin{tabular}{llll}
\hline $\begin{array}{l}\text { Name of the sub- } \\
\text { district }\end{array}$ & Location ${ }^{*}$ & $\begin{array}{l}\text { Human population } \\
\text { density }\end{array}$ & Type of farm \\
\hline Birganj & $26^{\circ} 0^{\prime} 0^{\prime \prime} \mathrm{N} 88^{\circ} 35^{\prime} 0^{\prime \prime} \mathrm{E}$ & $560 / \mathrm{km}^{2}(1,500 / \mathrm{sq} \mathrm{mi})$ & $\begin{array}{l}\text { Full Intensive and } \\
\text { Intensive household }\end{array}$ \\
& & & $\begin{array}{l}\text { yard } \\
\text { Dinajpursadar }\end{array}$ \\
$\begin{array}{l}25^{\circ} 38^{\prime} \mathrm{N} 88^{\circ} 39^{\prime} \mathrm{E} \\
\text { Kaharole }\end{array}$ & $25.7917^{\circ} \mathrm{N} 88.6000^{\circ} \mathrm{E}$ & $\begin{array}{l}520 / \mathrm{km}^{2}(1,300 / \mathrm{sq} \mathrm{mi}) \\
576 / \mathrm{km}^{2}(1,490 / \mathrm{sq} \mathrm{mi})\end{array}$ & $\begin{array}{l}\text { Full Intensive } \\
\text { Intensive household } \\
\text { yard }\end{array}$ \\
\hline
\end{tabular}

${ }^{*}$ Wikipedia (2017)

\section{Climate of the study area}

Dinajpur district has experienced a hot, wet and humid tropical climate. The district has a distinct monsoonal season, with an annual average temperature of $25^{\circ} \mathrm{C}\left(77^{\circ} \mathrm{F}\right)$ and monthly means varying between $18^{\circ} \mathrm{C}(64$ $\left.{ }^{\circ} \mathrm{F}\right)$ in January and $29^{\circ} \mathrm{C}\left(84^{\circ} \mathrm{F}\right)$ in August. Paddy, Maize, wheat and potato are main crops (Wikipedia, 2017).

\section{Farmer's selection}

Farmers were selected from the database of sub-district Livestock Office of Birganj, Kaharole and Dinajpur sadar. They were selected randomly from those who had experience of dairy buffalo farming and observation, secondary review, community discussion were held in the six months survey period from October 2016 to March 2017.

\section{Variables and data collection}

Variables included in this study were gestation period, calving interval, lactation period, dry period, feeding and management, milk production, breeding system and profitability.

Qualitative and quantitative information were collected from household yard intensive (HYI) and competently intensive (CI) farm. Data were collected directly from HYI farms through face to face interview. Discussions 
were conducted with 60 farmers rearing milking buffalo to validate the information gathered from HYI. Discussion was also conducted with the cowboys (hired labours) that provided additional strength to the obtained data. Same was done with two completely intensive system (CI) buffalo farms (who were rearing buffaloes since three decade).

Problem associated to buffalo farming were collected and rechecked with cowboys, veterinary field assistant (VFA) and upazilla livestock officer (ULO). The study therefore, follows the mixed methodology mode of Greene et al. (1989) focusing mainly on triangulation which can investigate the same issue with the same unit of analysis (Mitchell, 1986).

\section{Milk sample collection and analysis}

During the field visit, 15 individual milk samples (50 mL/sample) at animal level were collected from each type of intensive farms. The milk samples were immediately placed in a home freezer, transported in an ice box and placed in a regular freezer in the Dairy Chemistry Laboratory, Department of Dairy Science, Bangladesh Agricultural University, Mymensingh-2202, Bangladesh until further analyses. Milk samples were analyzed for fat, protein, lactose, solids-not-fat (SNF), and ash content, and Electric Conductivity (EC) by auto-milk analyzer (Lacto scan, Ultrasonic Milk Analyzer; Model MIA-SLP-60, S/N-70148; MILKOTONIC Ltd., Bulgaria 6000. Starazagora). Before the analysis, milk was tempered to $37^{\circ} \mathrm{C}$ with intermittent gentle inversion of the sample tubes.

\section{Identification of the problem matrix}

In order to understand the local perceptions regarding the problems of dairy buffalo farming, a simple proportional pilling tool (Catley, 2002) was used with two different groups of informant, each consisting of sixteen buffalo farmers. The informants were asked to think about related problem that might have challenged the dairy buffalo production. Top five problems were recognized by using 16 small stones.

\section{Data Analysis}

Descriptive statistics and independent sample T-test were done by using SPSS (version 16).

\section{Results and Discussion}

\section{Housing system}

Most of the houses were made by mud, bamboo and straw. At night farmers kept their animals in house. During day time, they kept the animals in household yard where animals took rest and fed straw, grass, water and small amount of concentrate under HYI system. But buffaloes in CI system were housed for the whole day and houses were built up of brick and tin. In the present study $100 \%$ farmers both in HYI and CI system cared for housing of their buffaloes. According to Siddiki (2017), $100 \%$ of the farmers in Subornochar, $80 \%$ for Trishal, $70 \%$ for Bagha and $45 \%$ for Lalpur sub-district didn't care about the housing for buffaloes under semi-intensive system. This is different from the present study; however, the production systems are different. In another study, Uddin et al. (2016) observed that dairy buffaloes were kept under semi-intensive system in the wet season and only $15 \%$ farmers provided shed having only roof but no concrete floor. Akbar et al. (2009) mentioned that most of the dairy buffaloes 
were not housed in extensive system of bathan areas but buffaloes which were in the plain land sometime had an enclosure, only roof made by straw or tin without wall and floor was always muddy.

\section{Feeding system}

The main diet for the buffalo was roughage such as natural grass, and paddy straw. The green grass fed either fresh as pasture or in a cut-and-carry-system. The roughage was often supplemented with grains, and/ or other concentrates e.g. wheat bran, oil cake, broken rice etc. A mix of concentrates, paddy straw, local grass and water were provided in the manger in HYI system during day time. But in night only straw and water were kept in the shed. Forage was found insufficient during the dry season and abundant during the rainy season.
The available feed ingredients and their supply to the dairy buffalo under HYI system is presented in Table 2. On fresh basis, rice gruel and wheat bran were found to be supplied at higher amount (1.53-1.71 kg fresh/ buffalo/day) than the other concentrates and agro-industrial by-products. But only $12.5 \%$ of the farmers used rice gruel to fed the dairy buffaloes which was one-sixth of the farmers used wheat bran in the ration of their dairy buffaloes. Ready feed was the lowest to be supplied to the dairy buffaloes followed by molasses but equal proportion of farmers $(25 \%)$ used them. Though the supply of protein rich ingredient, mustard oil cake was less than $0.2 \mathrm{~kg}$, most of the farmers $(63 \%)$ used it. The supply of cooked broken rice was 4-5 times of mustard oil cake but the proportion of users was similar. The supply of other concentrate items ranges from 0.14 to $0.16 \mathrm{~kg}$ fresh/buffalo/day and the user

Table 2. Available feed ingredients and their supply ( $\mathrm{kg}$ fresh/buffalo/ day) to dairy buffalo under HYI system

\begin{tabular}{llcc}
\hline Name of feed-base & Amount (mean) & Used by & farmers (\%) \\
\hline Rice gruel & 1.71 & 12.5 \\
Ready feed & 0.03 & 25 \\
Broken maize & 0.14 & 50 \\
Maize flower & 0.16 & 25 \\
Rice bran & 0.14 & 25 \\
Wheat bran & 1.53 & 75 \\
Cooked broken rice & 0.86 & 62.5 \\
Mustard oil cake & 0.19 & 62.5 \\
Molasses & 0.09 & 25 \\
Straw & 10.69 & 100 \\
Green grass cultivated/cut and carry & 6.22 & 50 \\
\hline
\end{tabular}

Table 3. Average feed allocation (fresh $\mathrm{kg} / \mathrm{buffalo} /$ day) based on fodder season under CI system

\begin{tabular}{|c|c|c|c|c|c|c|c|c|}
\hline Season & $\begin{array}{l}\text { Rice } \\
\text { gruel }\end{array}$ & $\begin{array}{c}\text { Broken } \\
\text { maize }\end{array}$ & $\begin{array}{c}\text { wheat } \\
\text { bran }\end{array}$ & $\begin{array}{c}\text { Cooked } \\
\text { broken } \\
\text { rice }\end{array}$ & $\begin{array}{l}\text { Mustard } \\
\text { oil cake }\end{array}$ & Molasses & Straw & $\begin{array}{l}\text { Green } \\
\text { grass }^{+}\end{array}$ \\
\hline Flush period $^{++}$ & 6 & 1.25 & 2.25 & 1 & 0.75 & 0.3 & 8.75 & 13.5 \\
\hline Lean Period ${ }^{--}$ & 6 & 1.25 & 3 & 2 & 0.75 & 0.3 & 13.25 & 5.5 \\
\hline
\end{tabular}

CI, Completely Intensive; + Green grass supplied from own cultivated land; ++ March-July (Five months); -- Aug-Feb (Seven months) 
proportion varies from 25 to $50 \%$. All of the farmers supplied straw to their dairy buffaloes but only $50 \%$ did so for green grass. The supply of paddy straw was almost double of the green grass.

Under CI system rice gruel was the major feed appeared to be supplied more than the other feed followed by wheat bran and broken maize. The supply of rice gruel, broken maize, mustard oil cake and molasses was not influenced by the availability of the fodder. On the other hand, the supply of wheat bran and cooked broken rice was found $0.75 \mathrm{~kg}$ and $1 \mathrm{~kg}$ more, respectively during the lean period than that of the flush period. Supply of green grass was reduced by 2.5 times during the lean period compared to the flush period which farmers tried to compensate by increasing the amount of straw by 1.5 times. Ahmed (2006) showed that wheat bran, rice polish, pea bran, khesari bran, matikalai bran, lentil, sesame oil cake, coconut oil cake and mustard oil cake were available round the year for dairy animals which supports the diversity of feeds in the present study. In the rainy and winter seasons, some legumes, green grasses were grown sporadically in some areas of the country and next six months availability of green grass becomes very limited. During this period, rice straw alone contributes $87 \%$ of roughage in dairy feed (Tareque, 1991). In present study buffalo farmers depends on dry roughage (paddy straw) and green grass and it mainly determined by seasonal phenomenon in those areas. These findings are also in line with Tareque, (1991). The dry matter intake (DMI) $(\mathrm{kg} / \mathrm{d})$ of milking buffaloes in different locations (coastal and river basin) was varied from 13-15 (kg/d) (Siddiki, 2017). The total feed supply also varied from $6.4-20.3 \mathrm{kgDM} /$ day/buffalo in coastal area under semi-intensive production system (Rahman et al., 2018). All these support well the findings of the present study regarding the total feed supply to the buffaloes.

\section{Watering}

Water requirements are influenced by many factors such as: species of animal, ambient temperature, body size, age, level of feed intake and daily milk yield (Marai and Haeeb 2010). Drinking water is the most important water source for buffalo for their body functions, e.g. maintaining body temperature, milk production and blood plasma volume (Buffalopedia, 2018). Irrespective of production system (HYI and CI), all the farmers (100\%) provided fresh drinking water to buffalo three times a day. Average water intake was $25-60$ L under HYI system. Under CI system, the water intake was found $15 \mathrm{~L}$ more during the summer season than that of the winter season (45 L). Mullick (1964) reported that the water consumption of dairy buffalo is 31.6 and $46.5 \mathrm{~L}$ during the winter and summer, respectively, supporting the present result. All these provide the evidence in favor of a greater variation in the water consumption based on several different factors as mention earlier.

\section{Wallowing and showering}

To keep the body cool and control the external parasites, buffaloes show wallowing behavior. In absence of water or marshy place buffalo behave similar to cattle, seeks shade and shower. Table 4 describes the wallowing and showering practices for buffaloes in two production system. Very few numbers of buffaloes $(11 \%)$ were allowed for wallowing at pond or river in summer season under HYI system. Under HYI system all farmers 
(100\%) provided shower to the buffaloes during November to June which was $11 \%$ less during July to October. Under CI system, all farmers provided their buffalo shower on household yard, however, frequency of showering was different in two different season of the year. Buffaloes when enter the water, they defecate and/or urinate to maintain temperature (buffalopedia, 2018). According to buffalo farmers, reduced feed intake, skin disease, delay heat and early abortion might be occurred in buffalo in absence of showering.
(AI) covered only $3.7 \%$ of the dairy buffaloes (Table 5). Most of the farmers were facing problem to breed their buffaloes during heat. As per the buffalo farmers, service of the buffalo might be missed due to the low number of breeding buffalo bull and long distance of AI service provider. Moreover, the transport cost (BDT 2500-3000) of buffalo in heat to the insemination center might impose an additional barrier on timely breeding of the dairy buffalo. More than half of the farmers used natural service to their buffalo in heat at the right time, while $42 \%$ of

Table 4. Practice of wallo wing and showering of buffaloes

\begin{tabular}{llllll}
\hline Production system & $\begin{array}{l}\text { \% of } \\
\text { farmer } \\
\text { practiced }\end{array}$ & $\begin{array}{l}\text { Name of the } \\
\text { practice }\end{array}$ & Period & Time & Place \\
\hline HYI & 11 & Wallowing & July to October & $1-2$ hrs/day & River/Pond \\
HYI & 89 & Showering & July to October & 2 time $/$ day & $\begin{array}{l}\text { River/Pond } \\
\text { HYI }\end{array}$ \\
& 100 & Showering & November- & $1-2$ time & $\begin{array}{l}\text { Household } \\
\text { yard }\end{array}$ \\
CI & 100 & Showering & December to & $1-2$ time & Household \\
& \multirow{2}{*}{100} & Showering & February - & $1-2$ time & Household \\
CI & & & November & /day & yard \\
\hline
\end{tabular}

\section{Breeding}

Almost all the dairy buffaloes (96.3\%) experienced natural mating under HYI system, whereas, artificial insemination farmers were unable to inseminate their animals in time due to various reasons (Uddin et al., 2016). Natural breeding was followed in CI system by the herd's breeding

Table 5. Breeding management of dairy buffalo under household yard intensive system

\begin{tabular}{ll}
\hline Variables & $(\%$ of buffalo) \\
\hline Type of breeding & \\
Natural breeding & 96.3 \\
Artificial insemination (AI) & 3.7 \\
Appearance of sign of heat & \\
Early morning & 11 \\
Noon & 3.2 \\
Afternoon & 5.7 \\
Evening & 12.4 \\
Early night & 47 \\
Late night & 20.7 \\
\hline
\end{tabular}


buffalo bull. A total of 79\% buffaloes showed heat from early night to early morning. Rahman et al. (2018) and Saadullah (2012) also observed that most the buffaloes showed breeding symptoms during the night which agreed with the present results.

The proportion of natural mating in the dairy buffaloes in Dinajpur district is in line with the finding of Uddin et al. (2016). They stated that the natural mating system was practiced by the most of the farmers though the number of breeding bull in the herd both in household and in bathan farming in Bangladesh is very minimum $(\approx 1 \%)$. Sawarkar et al. (2001) reported that, most of the farmers preferred natural service with the expectation that it would increase the conception rate. milk. In first stage of lactation (1 - 90 days), the buffalo had 2.5 and $4.5 \mathrm{~L} / \mathrm{d} / \mathrm{h}$ more milk production than the second stage of lactation (91 - 180 days), respectively in HYI and CI management system. In both systems, the daily per head milk production (L) in second stage of lactation was more than double of the milk production $(\mathrm{L} / \mathrm{d} / \mathrm{h})$ in the third stage (181 days - drying off) of lactation.

Significant difference was found in total solids $(p \leq 0.01)$, fat $(p \leq 0.001)$ and protein $(p \leq$ 0.01 ) content but SNF, lactose, ash, $\mathrm{pH}$ and electrical conductivity of buffalo milk were found similar $(\mathrm{p}>0.05)$ between two management system. Milk quality of buffaloes agrees with the report of Ling et al. (2013) who found that average milk fat, protein, lactose, total solid and non-fat solid

Table 6. Average milk production $(\mathrm{L} / \mathrm{d} / \mathrm{h})$ under HYI and CI system

\begin{tabular}{llll}
\hline Management system & $\begin{array}{l}\text { First stage } \\
(1-90 \text { days })\end{array}$ & $\begin{array}{l}\text { Second stage } \\
(91-180 \text { days })\end{array}$ & $\begin{array}{l}\text { Third stage (181days- } \\
\text { drying off })\end{array}$ \\
\hline HYI & 6.80 & 4.30 & 2.00 \\
CI & 11 & 6.5 & 2.5 \\
\hline
\end{tabular}

\section{Milk production and quality}

Average milk production $(\mathrm{L} / \mathrm{d} / \mathrm{h})$ according to the stage of lactation is shown in Table 6 and Table 7 shows the chemical quality of the of dairy buffalo were 7.52, 4.32, 5.19, 17.81, and 10.11 per cent, respectively in Mang city of China. The average value of buffalo milk component in the present study was also in agreement with the pooled values obtained

Table 7. Chemical quality of buffalo milk under Household Yard Intensive (HYI) and completely Intensive (CI) system

\begin{tabular}{llll}
\hline Parameter $(\%)$ & HYI $(\mathrm{n}=15)$ & $\mathrm{CI}(\mathrm{n}=15)$ & Level of significance \\
\hline Total solid & $16.43 \pm 1.03$ & $18.20 \pm 0.98$ & $* *$ \\
Fat & $6.86 \pm 0.65$ & $8.62 \pm 0.97$ & $* * *$ \\
SNF & $9.42 \pm 0.70$ & $9.49 \pm 0.29$ & NS \\
Lactose & $4.54 \pm 0.18$ & $4.66 \pm 0.14$ & NS \\
Ash & $0.67 \pm 0.05$ & $0.70 \pm 0.03$ & NS \\
Protein & $4.32 \pm 0.35$ & $3.86 \pm 0.22$ & $* *$ \\
$\mathrm{P}^{\mathrm{H}}$ & $6.20 \pm 0.42$ & $6.09 \pm .30$ & NS \\
EC & $3.25 \pm 0.49$ & $3.09 \pm 0.89$ & NS \\
\hline
\end{tabular}

$\mathrm{n}$, number of observation; ***, Significance at $0.1 \%$ level of probability; **, Significance at $1 \%$ level of probability; NS $=$ Non-significant; values are mean \pm Standard deviation. 
by Nahar et al. (2014) in Bangladesh. In another study, Islam et al. (2014) reported a lower protein $(3.5 \%)$ and fat $(5.84 \%)$ in buffalo milk from Bangladesh Livestock Research Institute herd than the present study but the lactose content is comparable. This may be due to different sample handling and method used and could explain these variations and since lactose present in true solution in milk, hence, is minimally affected.

\section{Productive and reproductive characters}

Productive and reproductive characters of dairy buffaloes under household intensive (HYI) and completely intensive (CI) system is shown in Table 8. The differences of lactation length (d), average milk yield (L/d), dry period (d), age at first pregnancy (month) and age at first calving (month) were found highly significant $(p \leq 0.001)$ between the management systems. The lactation yield of milk under CI system is double of the lactation milk yield of the HYI system. In CI system, $4 \mathrm{~L}$ more milk per day, 29 days of more lactation length and 75 days less dry period compared to the HYI management system explains the more lactation yield in CI system than the HYI system. The lactation yield in the household farming or semiintensive system and bathan farming or extensive system were 712-799 L and $435 \mathrm{~L}$, respectively (Faruque et al., 1990; Uddin et al., 2016) which were much lower than the Nili-Ravi buffaloes reported by Mudgal (1989), Khan (1995), and ICAR (2000), and half of the present findings. Lactation yield of our finding is also higher than the findings of Hussen (1990), Faruque and Amin (1995). Faruque and Amin (1995) found low lactation yield of indigenous buffaloes in Khulna region (280 L) and Hussen (1990) reported $830 \mathrm{~L}$ milk yield per lactation in Tangail which are lower than our findings. In our findings, the lactation yield was higher possibly attributed to the genotypic factors, since cross breed buffaloes are reared in HYI and CI system in Dinajpur district which are migrated/imported from India.

Compared to the HYI system, the buffaloes under CI system - required 34\% less service

Table 8. Productive and reproductive traits of dairy buffalo under HYI and CI system

\begin{tabular}{llll}
\hline Parameters & HYI & CI & $\begin{array}{l}\text { Level } \\
\text { of significance }\end{array}$ \\
\hline Lactation length (d) & $188.67 \pm 13.06$ & $217.22 \pm 6.18$ & $* * *$ \\
Lactation yield (L) & $1028 \pm 256.68$ & $2001 \pm 332.97$ & $* * *$ \\
Average milk yield (L/d) & $5.46 \pm 1.33$ & $9.22 \pm 1.56$ & $* * *$ \\
Dry period (d) & $172.67 \pm 22.73$ & $97.22 \pm 6.18$ & $* * *$ \\
Weaning age (d) & $199.33 \pm 19.28$ & $190.56 \pm 8.81$ & $\mathrm{NS}$ \\
Service per conception (number) & $2.00 \pm 0.58$ & $1.33 \pm 0.50$ & $*$ \\
Age at first pregnancy (month) & $35.42 \pm 3.48$ & $29.33 \pm 0.86$ & $* * *$ \\
Age at first calving (month) & $45.60 \pm 3.60$ & $39.33 \pm 0.86$ & $* * *$ \\
Calving interval (month) & $14.00 \pm 1.30$ & $12.89 \pm 1.16$ & $*$ \\
Gestation length (month) & $10.01 \pm 0.17$ & $10.00 \pm 0.00$ & $\mathrm{NS}$ \\
Post Partum heat period (month) & $4.23 \pm 0.89$ & $3.44 \pm 0.72$ & $*$ \\
\hline
\end{tabular}

HYI, Household Yard Intensive; CI, Completely Intensive; ${ }^{* * *}$, Significance at $0.1 \%$ level of probability; *, Significance at $5 \%$ level of probability; NS =Non-significant; values presented as mean \pm standard deviation 
per conception $(\mathrm{p} \leq 0.05)$, attained pregnancy 6 months earlier and therefore, gave birth of calf 6 months earlier ( $\mathrm{p} \leq 0.001$ ), had 2 months less calving interval and resumed their ovarian cyclicity 1 month earlier $(p \leq 0.05)$. The mean values of these variables found in the present study are in the comparable range of them reported by Karim et al. (2013), Faruque et al. (1990) and Shabede et al. (2003).

\section{Calf management}

Different components of calf management are presented in Table 9. At night, calves were kept separately on clean dry place at the corner of mother shed. Most of the farmers fed colostrums to new born buffalo calf suckling directly from their mother. Buffalo
Mishra (1987) stated that timely feeding of colostrums to calves is essential that leads to immunity of calves. At the age of one month, concentrate mixture (wheat bran, cake; 50-60 $\mathrm{g} / \mathrm{h} / \mathrm{d}$ ) and newly grown soft grass were offered to calf. A total of $36 \%$ farmers provided concentrate mixture just after one month of age. Only $13 \%$ farmers in HYI system provided water in separate manger which was mostly seen at CI system. Calf mortality was found $8 \%$ and $7 \%$, respectively in HYI and CI system. Ninety percent farmers noticed that diarrhorea and pneumonia were common diseases of buffalo calf which is similar to the findings of Islam et al. (2016) and Tiwari et al. (2007).

Table 9. Calf management practices in Dinajpur district

\begin{tabular}{lc}
\hline \multicolumn{1}{c}{ Parameters } & Values \\
\hline Colostrums feeding (\% of farmer) & 100 \\
Average amount of colostrums feeding (L/d) & $2.33 \pm 1.08$ \\
Average of interval of colostrums feeding (hrs) & $3.55 \pm 1.12$ \\
Providing water by separate manger (\% of farmer) & 13 \\
Providing concentrate mixture, one month age (\% of farmer) & 36 \\
Amount of concentrate mixture (g/d) & $50-60$ \\
Calf mortality (\%) under HYI & 8 \\
Calf mortality (\%) under CI & 7 \\
\hline
\end{tabular}

calves were fed 2-3 L colostrums per day maintaining 3-4 hrs intervals in study area in both type of system (HYI/CI). Sharma and

\section{Primary health care}

A total of $31 \%$ farmers used anthelmintic drug for internal parasite for milking buffalo

Table 10. Primary health care under Dinajpur district

\begin{tabular}{lc}
\multicolumn{1}{c}{ Parameters } & Values \\
\hline Use of anthelmintic under HYI & $31 \%$ \\
Use of anthelmintic under CI & $100 \%$ \\
Use of vaccine under HYI & $23 \%$ \\
Use of vaccine (FMD and HS) under CI & $100 \%$ \\
\hline
\end{tabular}


but $23 \%$ farmers followed vaccination practice under HYI system (Table 10). In CI system all farmers used anthelmintic for controlling both external and internal parasite and used vaccine to their buffaloes. The FMD and HS vaccine commonly used for both systems.

\section{Economics of buffalo farming}

Yearly expenditure, gross income and net income in HYI system were BDT 140000 , BDT 200000 and BDT 60000, respectively. The benefit cost ratio (BCR) was found as 1.33 in HYI system. Benefit and cost of completely intensive (CI) buffalo farming is presented in Table 11.

Yearly expenditure, gross income and net income were BDT 968810, BDT 1220525 and BDT 251715 respectively in CI system farm. Yearly Benefit Cost Ratio (BCR) was found as 1.25. Moreover total remaining assets were BDT 1060000 which represents of present value of buffalo herd of CI system (Table 11). Hasan et al. (2016) reported that buffalo rearing in the coastal areas of Bangladesh was highly profitable. It may be a crucial pathway for poverty alleviation. Rahman et al. (2008) stated that the benefit cost ratio was 1.31 , indicating that buffalo rearing was profitable in Bangladesh which is agreed with the findings of Islam et al. (2017) and Siddiki et al. (2017) and also support to present study.

\section{Problems of dairy buffalo production system}

Problem matrix represented percentage of score to assess dairy buffalo-derived problems illustrated in Table 12.

Table 11.Cost-benefit of completely intensive (CI) buffalo farming (1USD=BDT83)

\begin{tabular}{|c|c|c|c|c|c|c|c|c|}
\hline \multicolumn{2}{|l|}{$\begin{array}{l}\text { Herd } \\
\text { composition } \\
\text { and items }\end{array}$} & $\begin{array}{l}\text { Unit } \\
\text { price(BD) }\end{array}$ & $\begin{array}{l}\text { Yearly } \\
\text { total } \\
\text { cost } \\
\text { (BDT) }\end{array}$ & $\begin{array}{l}\text { Yearly } \\
\text { Gross } \\
\text { income } \\
\text { (BDT) }\end{array}$ & $\begin{array}{l}\text { Yearly } \\
\text { net } \\
\text { income } \\
\text { (BDT) }\end{array}$ & $\begin{array}{l}\text { Net } \\
\text { income } \\
\text { Monthly } \\
\text { (BDT) }\end{array}$ & $\begin{array}{l}\text { Remaining } \\
\text { asset } \\
\text { (Unit Price) }\end{array}$ & $\begin{array}{l}\text { Total } \\
\text { Remaining } \\
\text { asset }\end{array}$ \\
\hline $\begin{array}{l}\text { Milking } \\
\text { buffaloes }\end{array}$ & 8 & $\begin{array}{l}\text { Total milk } \\
\text { production } \\
45 \mathrm{~L} / \text { day, } \\
\text { BDT } 53 / \mathrm{L}\end{array}$ & - & 870525 & - & - & $\begin{array}{l}640000 \\
@ 80000\end{array}$ & - \\
\hline $\begin{array}{l}\text { Dry } \\
\text { buffaloes }\end{array}$ & 4 & - & - & - & - & - & $\begin{array}{l}280000 \\
@ 70000\end{array}$ & - \\
\hline Heifer & 1 & - & - & - & - & - & $\begin{array}{l}65000 \\
@ 65000\end{array}$ & - \\
\hline Bull & 1 & - & - & - & - & - & $\begin{array}{l}75000 \\
@ 75000\end{array}$ & - \\
\hline Calf & 7 & 50000 & & 350000 & - & - & - & - \\
\hline $\begin{array}{l}\text { Concentrate } \\
\text { feed }\end{array}$ & & 18 & 643860 & - & - & - & - & - \\
\hline Straw & & 3 & 229950 & - & - & - & - & - \\
\hline Labour & 1 & 7500 & 90000 & - & - & - & - & - \\
\hline Other & & & 5000 & - & - & - & - & - \\
\hline Total & & & 968810 & 1220525 & 251715 & 20976 & & 1060000 \\
\hline BCR & 1.2 & & & & & & & \\
\hline
\end{tabular}


Table 12. Problem matrix for assessing dairy buffalo-derived problems

\begin{tabular}{llc}
\hline Name of the problem & \multicolumn{2}{c}{ of the } \\
score & $\begin{array}{c}\text { Ranked } \\
\text { order }\end{array}$ \\
\hline Inadequate knowledge /lack of training facilities & 18 & 1 \\
High price of feed & 15 & 2 \\
Low milk price & 14 & 3 \\
Shortage of feeds \& fodder & 11 & 4 \\
High temperature & 10 & 5 \\
Lack of cow boy & 9 & 6 \\
Limited Breeding bull & 7 & 7 \\
Lack of AI workers and inadequate quality semen & 7 & 7 \\
Lack of financial facilities as credit & 7 & 7 \\
Buffalo as draught animal & 4 & 8 \\
\hline Total & 100 & \\
\hline
\end{tabular}

Buffalo farmers identified several problems for buffalo production system which lead the reason of decreasing buffalo population (Table 12). Inadequate knowledge due to lack training facilities, high feed price, low milk price were the main challenge for dairy buffalo production. Buffalo farmers were deprived from milk selling as they were not get milk price according to milk fat.

Milkman was milking from buffalo cow in HYI system and they purchased milk from farmers. But low milk price (40-42 BDT/L) was found in HYI system. Milk sold to local market and sweetmeat shop. Some time milk man didn't come to collect milk and farmer became looser. They gave money to farm owner quarterly or monthly basis. Buffalo farmer's, therefore, depends on middle man for pricing of milk in HYI system. But in CI system, farmer sold milk directly to sweetmeat shop and get relatively higher price (50-55 BDT/L) than HYI system.

\section{Conclusion}

The findings of the present study revealed that two types of production systems of dairy buffaloes under intensive farming were found in the drought prone area under Dinajpur district. The housing types and management, availability of feed resources and its utilization, wallowing and showering and access to the primary animal health care were not similar between these two systems. Seasonal influence was found in most of the management decision. The productivity and milk quality was found better under completely intensive system than the household yard. The benefit cost ratio (BCR) was found profitable in both systems. But farmers are facing some problems to rear the dairy buffaloes. They indicated "lack of knowledge", "high price of feed" and "low milk price" as the main challenges for the sustainability of the buffalo farming. Government/ NGOs would provide skill training to buffalo farmers for improving relevant modern knowledge. Improvement of market value chain might be helpful to minimize the feed cost and will help farmers for getting good milk price. So, the future perspective could betraining and marketing interventions that might be helpful for economic sustainability of intensive dairy buffalo farmers that would contribute 
significantly in national economy.

\section{Acknowledgement}

The authors are grateful to BAS/USDA for financial support to conduct this study. The authors also highly acknowledge the support of Upazilla Livestock Office for their cordial help to collect the data during field survey.

\section{References}

Ahmed, T.U. 2006. Studies on nutritional status of dairy cows of Bangladesh and improvement of their productive and reproductive performance in Baghabarighat area through nutritional manipulation, $\mathrm{PhD}$ Thesis, Department of Animal Nutrition, Bang. Agri. Univ., Mymensingh.

Akbar, M.A., Faruque, M.O. and Islam, M.N. 2009. Current dairy feeding and management systems: Dairy buffaloes. In. Hand Book of Dairy Nutrition- Bangladesh [Published by American Soybean Association: International Marketing, edited by Peter $H$. Robinson and $U$. Krisnamorthy] New Dilhi, India 50-64.

Bilal, M.Q., Suleman M. and Raziq, A. 2006. Buffalo: Black gold of Pakistan. Live. Res.For Rural Dev., 18 (9): 2006.

Buffalopedia. 2018. Institute for Research on Buffaloes, Indian Council of Agricultural Research, Department of Agricultural Research and Education, Ministry of Agriculture, Government of India : http://www.buffalopedia.cirb.res.ina

Catley, A. 2002. Monitoring and assessment of community based animal health project, In hand book of community- base animal health care: a practical guide to improving primary veterinary services (compiled by Andy Catley, Steplen Blakeway and Tim Leyland, Published by ITDG publishing, South Hampton Row, London WCIB 4HL, UK, ISBN 1 85339485 8) Chapter 6, p 210

DLS. 2018. Directorate of Livestock Services Krishi Khamar Sarak Farm Gate. Dhaka. Available on http:/www.dls.gov.bd/site/ page/ 22 b 1143 b-9323 - 44 f8 - b fd 8 647087828c9b/ Livestock- Economy23/ 12/2018. 1.17 PM

DLS. 2016. Directorate of Livestock Services. Annual Report 2015-16. Krishi Khamar Sarak Farm Gate.Dhaka.

FAO, 2010. Food and Agricultural Organization of the United Nations. Production Year book 2010, FAO, Rome, Italy.

Faruque, M.O. and Amin, M.R. 1995. Indigenous buffalo in coastal area of Bangladesh: Part II. Productivity of indigenous buffaloes in the South Western coastal area. Bangladesh J. Training and Dev., 8 (1 \& 2): 138-140.

Faruque, M.O., Hasanath, M.A. and Siddique, N.U. 1990. Present status and productivity of buffaloes in Bangladesh raised by the small farmers. Asian-Aust. J. Anim. Sci., 3(4): 287-292.

Greene, J.C., Caracelli, V.J. and Graham, W.F. 1989. Toward a Conceptual Framework for Mixed- Method Evaluation Designs. Edu. Eval.and Policy Analy., 11 (3): 255-274.

Hasan, T., Akter, S., Biswas, H., Halim, M.A., Alam, A., Rafiq, K. 2016. Economic analysis of small scale dairy buffalo enterprises in Bhola district of Bangladesh. Prog. Agri., 27 (4): 502510, 2016.

Huque, K.S. and Khan, M.Y.A. 2017. Socio-geographic distribution of livestock and poultry in Bangladesh-a review. Bang. J. of Anim. Scie., 46 (1): 65-81. 
Hussen, M.S. 1990. Performance of indigenous buffaloes in Tangail district. M.Sc. Thesis. Bangladesh Agric. Univ. Mymensingh.

ICAR- International Committee for Animal Recording. 2010. Yearly inquiry on the situation of milk recording in buffalo. Rome, Italy.

Islam, M.N. 2017. Challenge of animal protein for national health security: Keynote paper presented at 4th (BSAPER) International Conference 6 May, 2017. Bangladesh Agric. Univ., Mymensingh.

Islam, K.B.M.S., Kabir, M.H.B., Rahman, M.H. and Kabir, M.H. 2016. Status of buffalo disease in Bangladesh in relation to casual agents and predisposing factors. Int. J. of Liv. Sci. and Tech., 9(5), 44-50.

Islam, M.A., Ekeberg, D., Rukke, E.O. and Vegarud G.E. 2015. Ex vivo digestion of omega-3 enriched buffalo skimmed milk. J. of Func. Foods., Vol 19, Part B, P 842-851. https://doi.org/10.1016/j.jff.2014.08.016

Islam, M. A., Alam, M. K., Islam, M. N., Khan, M. A. S., Ekeberg, D., Rukke, E. O. and Vegarud, G. E. 2014. Principal Milk Components in Buffalo, Holstein Cross, Indigenous Cattle and Red Chittagong Cattle from Bangladesh.Asian-Australas J Anim Sci. 27(6): 886-897. doi: 10.5713/ajas.2013.13586

Karim, M.R., Hossain, M.Z., Islam, M.R., Parvin, M.S. and Matin, M.A. 2013. Productivity reproductively and management system of indigenous buffalo (Bubalus bubalis) cows in coastal areas of Pirojpur and Borguna district of Bangladesh. Progress. Agric., 24 (1 \& 2): 117 - 122, 2013 ISSN 1017-8139.

Khan, M.S. 1995. Genetic potential of buffaloes raised under farm condition in
Bangladesh. M.S. Thesis, Bangladesh Agric. Univ., Mymensingh.

Ling, X.Y., Tao C, Kun, T.S., Sheng, Z.H., Bing, N. Z., Ping H.G. and Hai, F.X. 2013. Report on DHI of dairy buffalo in Mang City in Yunnan province, China. China-Cattle-Sci., 39(5): 73-78.

Marai, I.F.M and Haeeb, A.A.M. 2010. Buffalo's biological functions as affected by heat stress -A review. Liv. Sci., 127 (2010) 89-109

Mitchell, E.S.1986. Multiple Triangulations: A Methodology for Nursing Science. Adv. in Nur. Sci., 8 (3): 18-26.

Mudgal, V.D. 1989. The role of riverine buffaloes in small farm systems in Asia. Proc. Symp. Buffalo Genotypes for small Farms in Asia Univ., Pertinian, Malaysia. 1-9.

Mullick, D.N. 1964. A study on the metabolism of food nutrients in cattle and buffaloes under climatic stress. Arid Zone Res., 14, 137.

Nahar, T.N. 2011. Training manual on buffalo management. Bangladesh Livestock Research Institute, Savar, Dhaka 1341.

Nahar, T.N., Alam, M.K. and Akhtar, S. 2014. Study the assessment of nutritional composition and bacterial load in buffalo milk in some selected areas of Bangladesh. Proceeding of the Annual Research Review Workshop 2012-13. Bangl. Live. Res. Ins., Savar, Dhaka 1341.

Nanda, A.S. and Nakao, T. 2003. Role of buffalo in the socio-economic development of rural Asia: Current status and future prospect. Anim. Sci.J.,74 : 443-455.

Rahman, S.M.R., Islam, M.N., Rashid, M.H., Siddiki, M.S.R. and Islam, M, A. 2018. 
Dairy buffalo production system under semi-intensive management in the coastal area of Bangladesh. SAARC J.of Agri., 16(2): 43-59. DOI: https://doi.org/ 10.3329/sja.v16i2.40257

Rahman, S.M.R. and Islam, M.N. 2018. Dairy buffalo farming under intensive system in semi arid area ofBangladesh, Book of abstract, Asian Buffalo Congress (ABC), 1-4 February, 2018, ICAR Central Institute of Research on Buffaloes, Hisar, India.

Rahman, S.M.R., Islam, M.N., Siddiki, M.S.R. 2017. A case study of milking buffalo farming under intensive system in semi arid area of Bangladesh: Dinajpur experience. Proc., 4th (BSAPER) International Conference 6 May, 2017. Bangladesh Agric. Univ., Mymensingh.

Rahman, S.M.A., Begum, J.B., Sayeed, M.A., Hossain, M. and Alam, J. 2008: Economics of buffalo production in some selected areas of Bangladesh. Bang. J. of Liv. Res., 15: 39-46.

Saadullah, M. 2012. Buffalo production and constraints in Bangladesh. J.of Anim. and Plant Sci., 22(3 Supplement), 221-224.

Sawarkar, S.W., Borkar, M.M., Upadhye, S.V. and Jadhao, S.B. 2001. Characteristics of dairy owners, their awareness, adoption and constraints in adoption of artificial insemination practices in Vidarbha region. Indian J. Dairy Sci., 54: 194-202.

Shabade, N.S., Jagtap, D.Z. and Behle, N.D. 1993. Factors affecting production and production efficiency traits of first lactation Murrah buffaloes. Indian J. Ani. Sci., 63(11): 1212-1213.
Sharma, M.C. and Mishra, R.R. 1987. Livestock health and management. Khanna Publishers, New Delhi.

Siddiki, M.A. 2017. Improvement of production potential of buffaloes supplemented with protein and energy based diets. $\mathrm{PhD}$ thesis. Department of Animal Science. Bangladesh Agric. Univ., Mymensingh.

Soliman, I. 2007. Economic Feed Utilization for Dairy Buffalo Under Intensive Agricultural System, It. J. of Anim. Sci., 6:sup2, 1367-1375, https://doi.org/ 10.4081/ijas.2007.s2.1367

Tareque, A.M.M. 1991. Feeds and Fodder Resources in Bangladesh and Patterns of Utilization, ADB, Second Livestock Project, Dhaka, Bangladesh.

Tiwari, R., Sharma, M.C. and Singh, B.P. 2007. Buffalo calf health care in commercial dairy farms: a field study in Uttar Pradesh (India). Lives. Res. for Rural Dev., 19(3).

Uddin, M.K., Mintoo, A.A., Awal, T.M., Kondo, M. and Kabir, A.K.M.A. 2016. Characterization of buffalo milk production system in Bangladesh. Bang. J. Anim. Sci., 45 (1): 69-77.

Wikipedia. 2017. Bangladesh map of Köppen climate classification. Available on https:// upload. wikimedia.org/ wikipedia/ commons/9/94/Bangladesh_map_of_K\% C3\% B6ppen_climate_classification.svg. 20/11/2017. 15.44 PM. 